\title{
PALATALIZAÇÃO DAS PLOSIVAS ALVEOLARES EM FLORES DA CUNHA (RS): VARIAÇÃO LINGUÍSTICA E PRÁTICAS SOCIAIS
}

\author{
Elisa BATTISTI* \\ Adalberto Ayjara DORNELLES FILHO **
}

- RESUMO: A palatalização variável das plosivas alveolares no português brasileiro falado em Flores da Cunha é moderada, o que contribui para caracterizar o falar local. A análise de regra variável (LABOV, 1972, 1994, 2001) de dados de 48 entrevistas sociolinguísticas de Flores da Cunha do BDSer revela uma proporção total de aplicação de $29 \%$. Os condicionamentos são tanto linguísticos quanto sociais e a palatalização progride na comunidade: jovens, vogal alta fonológica, habitantes de zona urbana e consoantealvo desvozeada favorecem a palatalização. Na análise da variação como prática social (ECKERT, 2000), o estudo da rede social dos informantes mostra que a alta densidade da rede, nucleada por informantes de grupos etários mais velhos, refreia a palatalização. O estudo etnográfico revela que os habitantes de Flores da Cunha, em especial os jovens, realizam práticas sociais inovadoras ao lado de práticas tradicionais, introduzindo a palatalização na comunidade. O emprego das formas palatalizadas é valorado como não local e é relativamente prestigiado.

- PALAVRAS-CHAVE:Variação linguística. Palatalização. Plosivas alveolares. Práticas sociais.

\section{Introdução}

O português falado no Brasil tem características fonético-fonológicas resultantes dos contatos linguísticos ocorridos ao longo da história do país, alguns ainda em andamento. Na antiga região colonial italiana do Rio Grande do Sul (RCI-RS), Estado situado no extremo Sul do Brasil, o português guarda, do contato com o italiano, alternâncias como o emprego de vibrante simples em lugar de múltipla em onset silábico (churrasco churasco, carro caro); de -on em lugar de -ão (pão pon, caminhão caminhon). Essas características constroem o sotaque local. Outros traços variáveis contribuem para essa construção, não porque se originem do contato italiano-português, mas porque, bastante frequentes em outras variedades de português brasileiro, têm baixa ocorrência no português

* UFRGS - Universidade Federal do Rio Grande do Sul. Instituto de Letras. Porto Alegre - Rio Grande do Sul Brasil. 91540-000 - elisa.battisti@pq.cnpq.br

** UCS - Universidade de Caxias do Sul. Centro de Ciências Exatas e Tecnologia. Caxias do Sul - Rio Grande do Sul - Brasil. 95070-560 - aadornef@ucs.br 
falado na região. É o que acontece com a palatalização das plosivas alveolares /t/ e /d/ (tia [tS]ia, dia [dZ]ia, parte par[tS]i, onde on[dZ]i).

No presente estudo, analisa-se a palatalização variável de /t/ e /d/ no português falado em Flores da Cunha, pequeno município de base étnica italiana localizado na RCI-RS. Além dos condicionamentos linguísticos e sociais do processo, objetiva-se verificar a proporção total de aplicação da regra, sua tendência a progredir, regredir ou estabilizar-se no sistema da comunidade e o valor social das formas palatalizadas.

A questão a que se procura responder relaciona-se ao padrão de palatalização de outros municípios da região, Antônio Prado e Caxias do Sul. A proporção de aplicação não ultrapassa os 30\%. O processo tende a se estabilizar na primeira comunidade e a progredir na segunda. Já na capital do Estado, Porto Alegre, a palatalização supera os 90\%. Qual é o padrão de Flores da Cunha? Que elementos da cultura local, da estrutura linguística e social sustentam esse padrão?

O estudo desenvolve-se na perspectiva da variação linguística como prática social (ECKERT, 2000), uma abordagem que aproxima sociolinguística de antropologia, articulando análise quantitativa e análise qualitativa. Para dar conta dessa articulação, são realizadas análise de regra variável (LABOV, 1972, 1994, 2001), análise de rede social (MILROY, 1980) e estudo etnográfico, que contempla observação participante e análise discursiva das entrevistas sociolinguísticas.

Mostraremos que a palatalização em Flores da Cunha é condicionada tanto por variáveis linguísticas quanto sociais. O processo correlaciona-se ao status da vogal-gatilho da regra, à qualidade da consoante-alvo, à idade dos informantes e a seu local de residência. A menor aplicação da regra na zona rural relaciona-se a diferenças na estrutura e no conteúdo da rede social. As formas palatalizadas são salientes para os florenses, que as percebem como não locais, num quadro de práticas sociais tradicionais mescladas a tendências sociais globais.

O artigo se estrutura em seis seções, cinco além desta. Na seção seguinte, Fundamentação Teórica, descreve-se a palatalização das plosivas alveolares do ponto de vista fonético e em suas repercussões sociais e abordam-se os fundamentos das análises quantitativa e qualitativa de processos variáveis. Na Revisão de Literatura, revisam-se alguns estudos sobre a palatalização das plosivas alveolares com dados do Sul do Brasil. Na seção Metodologia, detalhamse os procedimentos seguidos nas análises realizadas: de regra variável, de rede social, etnográfica. Os resultados são apresentados e discutidos na quinta seção do trabalho, este finalizado com a Conclusão. 


\section{Fundamentação teórica}

\section{A palatalização das plosivas alveolares}

Palatalização é um processo assimilatório, envolve a adoção, por um segmento, de características de segmentos vizinhos. A característica em questão é o emprego da lâmina/corpo da língua na articulação do segmento. Na palatalização das plosivas alveolares, /t/ e /d/ assimilam tal característica articulatória da vogal alta seguinte - /i/, como em tia, dia, ou [i] derivado de /e/, como em parte, onde. Além da palatalização propriamente dita, as consoantes sofrem africatização, isto é, há um pequeno escape de ar ao final da articulação.

Em estudos sobre o português brasileiro em contato com o italiano (FROSI; MIORANZA, 1983), registra-se a baixa aplicação dessa regra variável, o que constitui um traço característico desse falar em oposição aos falares monolíngues-português, em que a palatalização é mais difundida. É o que se verifica em Flores da Cunha: a não palatalização das plosivas alveolares caracteriza o português local. Isso é percebido pelos próprios habitantes, o que contrasta com a pronúncia palatalizada dos indivíduos "de fora", os monolíngues-português.

Pagotto (2001), em estudo sobre o português falado em Florianópolis, verificou a existência de questões de identidade envolvidas no emprego de plosivas palatalizadas e não palatalizadas. Naquela localidade, as questões resultam da tensão entre os habitantes da ilha e os "de fora", veranistas e novos habitantes vindos de outros lugares do Brasil e exterior, que invadiram a ilha a partir do processo de reurbanização ocorrido nas últimas décadas. Empregar uma ou outra forma adquire valor social, reveste-se de significados que nascem do conjunto de práticas que o uso da língua integra.

É nesse sentido que se estuda a regra variável de palatalização, como processo variável dirigido por restrições linguísticas e sustentado por valores ou significados que se originam nas práticas sociais.

\section{Variação linguística e práticas sociais}

Os estudos de variação linguística conformes à Teoria da Variação (LABOV, 1972, 1994, 2001) têm como objeto as formas alternativas de dizer a mesma coisa, naquilo que informam sobre as regras que estão por trás da variação. Tais estudos buscam generalidades preditivas sobre a realização linguística em uma comunidade de fala, para o que uma considerável quantidade de dados variáveis e seu tratamento quantitativo são necessários. Seguem o pressuposto de que 
a variação linguística, além da motivação interna (linguística), tem motivação externa (social): correlaciona-se à classe social, etnia, idade, sexo/gênero dos indivíduos, entre outras características.

Nessa perspectiva, a língua não é propriedade do indivíduo, mas da comunidade. O indivíduo herda da comunidade o sistema da língua (a variação, inclusive). Os informantes são representantes da comunidade e a comunidade é definida pelo analista através das categorias sociais que propõe e controla na análise. O que define a comunidade de fala são os padrões de uso da língua e não o indivíduo ou a fala individual. Por exemplo, a realização e os padrões de uso da palatalização das plosivas alveolares é uma das características que distinguem a comunidade de falantes de português brasileiro da comunidade de falantes de português europeu.

Além dessa análise, a investigação do valor social atribuído às variantes, na linha de Eckert (2000), requer considerar que os falantes constituem, e não apenas representam, categorias sociais. O significado social da variação não é apenas reflexo da pertença ou forma de reclamar pertença a categorias, mas está relacionado às práticas que dão origem e mantêm as categorias e que tornam a pertença a elas significativa: as formas alternantes são valoradas conforme o prestígio da comunidade, o indivíduo é valorado conforme o grau de adesão à comunidade. Esta não é mais vista apenas como comunidade de fala, mas como comunidade de prática. É na comunidade de prática, e no mercado linguístico (BOURDIEU, 2008) aí estabelecido, que os falantes são avaliados, que se dá significado para as suas diferenças.

Num município como Flores da Cunha, como em qualquer outro, muitas são as comunidades de prática, onde símbolos como a origem familiar e a linguagem, entre outros, convertem-se em patrimônio, em capital cultural que compete no mercado de bens simbólicos locais, regionais e nacionais e contribui para a distinção simbólica e para a visibilidade do grupo.

Acreditamos que, não só em Flores da Cunha, mas na região como um todo, a baixa palatalização seja recurso estilístico que permita aos descendentes de italianos (e de outras etnias que porventura residam hoje na comunidade) realizarem práticas sociais locais como forma de diferenciarem-se no cenário estadual e nacional e, assim, ganharem visibilidade, mesmo que elementos não locais sejam também experimentados na comunidade.

As relações dos falantes em redes sociais têm efeitos sobre seu comportamento linguístico, o que sustenta e explica a emergência das variantes. Milroy (1980) faz uma análise da modalidade não padrão do irlandês falado em três bairros de classe trabalhadora ${ }^{1}$ de Belfast, no que se refere aos padrões variáveis de realização vocálica, predominantemente. A cuidadosa

Do inglês working-class neighborhoods. 
quantificação da variação, correlacionada à rede social dos informantes, revelou que a predominância de alternantes não padrão reflete os padrões de interação social das comunidades em redes. Não é a classe baixa o que determina o emprego de variantes não padrão, mas a identidade de grupo que, por sua vez, nasce de uma coesão originada nas próprias condições de sobrevivência do grupo, em suas práticas sociais, que se dão basicamente num único território. O sentimento de pertença ao bairro e o valor social (positivo) a ele atribuído Milroy denomina localismo.

Conforme Evans (2004), as redes apresentam diferenças em sua configuração em duas dimensões, a da estrutura (ou densidade) e a do conteúdo (plexidade)². A densidade refere-se à quantidade de contatos dos indivíduos: quanto maior o número de pessoas em rede que se conhecem umas às outras, maior sua densidade. Uma rede em que poucos indivíduos conhecem-se mutuamente é uma rede frouxa, de baixa densidade. À estrutura da rede importa o fato de os membros conectarem-se uns aos outros por mais de um tipo de relacionamento (colega de trabalho e, ao mesmo tempo, vizinho). Uma rede na qual os indivíduos se relacionam de múltiplas maneiras é uma rede multiplexa, uma rede na qual os indivíduos se relacionam de uma única maneira é uniplexa.

\section{Revisão de literatura}

Battisti e Guzzo (2010) fazem uma extensa revisão de estudos sobre a palatalização das plosivas alveolares com dados do Sul do Brasil realizados na perspectiva sociolinguística laboviana, em análises de regra variável. A maior parte deles diz respeito a falares do Rio Grande do Sul e a constatação das autoras é a de que, exceto Porto Alegre, em que a aplicação da palatalização tem frequência superior a 90\%, as comunidades gaúchas apresentam taxa de palatalização de baixa à moderada. Isso poderia ser indício de a regra estar se expandindo da capital para o interior, não fosse o comportamento de algumas comunidades em que a palatalização é variação estável e aplica-se em níveis moderados.

É o caso de Antônio Prado, estudado por Battisti et al. (2007) com dados do BDSer ${ }^{3}$. Os autores verificaram que a frequência total de aplicação da palatalização é de $30 \%$ e o processo é favorecido por vogal alta fonológica /i/ (a redução de /e/ átono em Antônio Prado é baixa) como também por jovens habitantes da zona urbana do município. Embora haja um aumento na frequência de palatalização

\footnotetext{
Em inglês, os termos correspondentes a densidade e plexidade são density e plexity, respectivamente.

3 Banco de Dados de Fala da Serra Gaúcha, da Universidade de Caxias do Sul. É um acervo de entrevistas sociolinguísticas iniciado, em agosto de 2000, por um grupo de pesquisadores da UCS integrado pelos autores deste artigo. O acervo contém 55 entrevistas de Caxias do Sul, 55 de São Marcos, 57 de Antônio Prado e 56 de Flores da Cunha.
} 
com o declínio da idade do informante, as taxas se estabilizam nas faixas etárias mais jovens, o que leva a crer que a regra em Antônio Prado não seja variação num processo de mudança, mas alternância que tenda a estabilizar-se no sistema linguístico em índices modestos. A análise da rede social dos informantes revela que a relação em rede de informantes da zona rural de Antônio Prado sustenta o emprego de alternantes conservadoras, no caso, as variantes não palatalizadas. Os de zona urbana participam de redes densas, porém os laços inter-individuais são menos íntimos, assim menos reforçadores de um falar local, possibilitando o emprego de alternantes menos conservadoras, as variantes palatalizadas na análise.

Nas demais comunidades, a regra está em progressão, mas em ritmos diferentes. É o que constata Bisol (1986) em seu estudo pioneiro. A autora analisou a palatalização das plosivas /t/ e /d/ na fala de 60 informantes de quatro grupos geográficos do Rio Grande do Sul: 15 de Porto Alegre, monolíngues-português; 15 de Livramento, fronteira do Rio Grande do Sul com o Uruguai, onde se vivencia o contato português-espanhol diariamente; 15 de Taquara, bilíngues português-alemão; e 15 de Monte Bérico, Veranópolis, bilíngues português-italiano. A frequência total de aplicação foi de $65 \%$, com a seguinte distribuição: 90\% em Porto Alegre, 79\% em Livramento, 60\% em Taquara e 18\% em Monte Bérico. A autora verificou que a palatalização é favorecida pelos metropolitanos e fronteiriços, desfavorecida por italianos e alemães, oposição que se mantém nos resultados da variável Sílaba: nos metropolitanos e fronteiriços, o processo é favorecido nas posições relativamente mais fortes da palavra; nos italianos e alemães, nas posições mais fracas. Jovens palatalizam mais em todos os grupos étnicos. A autora registra a interação entre a palatalização e a regra de elevação de /e/ átono, a última alimentadora da primeira.

A palatalização em Flores da Cunha foi investigada por Almeida (2000) em dados do VARSUL ${ }^{4}$. O autor levantou contextos de 24 entrevistas sociolinguísticas e, neles, a frequência total de aplicação da regra foi de $47 \%$. O autor acredita que o processo esteja em aquisição na comunidade. Foram controladas as variáveis linguísticas Contexto Fonológico Precedente e Seguinte, Sonoridade, Tonicidade, Tipo de Vogal Alta; e as variáveis extralinguísticas Idade, Escolaridade e Sexo/ Gênero. Favorecem a palatalização os fatores vogal, vibrante, fricativa alveolar precedente, lateral e labial seguinte, como também oclusiva surda /t/, sílaba postônica final e vogal alta derivada de /e/ átono. As três variáveis sociais mostraram-se relevantes para o processo: promovem a palatalização as mulheres, os indivíduos que completaram o ensino médio e aqueles com menos de 50 anos

\footnotetext{
O projeto VARSUL (Variação Linguística na Região Sul do Brasil) tem por objetivo geral a descrição do português falado e escrito de áreas socioculturalmente representativas do Sul do Brasil. Constituem seu acervo o Banco de Dados VARSUL, a Amostra Digital VARSUL e o Banco de Dados Diacrônico. Disponível em: <http:// www.varsul.org.br/>. Acesso em: 8 fev. 2012.
} 
de idade, o que permite ao autor afirmar a existência de mudança em progresso na comunidade, conduzida pelas mulheres ao adotarem a variante de maior prestígio.

Matté (2009) testou a hipótese de que Caxias do Sul (RS) difundiria a palatalização de /t d/ a municípios vizinhos. Fez análise de regra variável de dados levantados de 16 entrevistas sociolinguísticas do BDSer. Foram 9.006 os contextos, cuja análise revelou uma proporção de 35\% de palatalização. Como essa taxa é próxima à de Antônio Prado para o processo, a hipótese inicial não se confirmou. A maior diferença entre as duas cidades está no fator 18-29 anos da variável Idade: $72 \%$ em Caxias do Sul, 42\% em Antônio Prado. O autor discutiu a ideia de que os jovens de Caxias do Sul talvez usem a regra temporariamente e, mais tarde, voltem a falar como os mais velhos, com o que se mantém a palatalização moderada.

\section{Metodologia}

\section{Flores da Cunha}

A comunidade investigada no presente estudo é, como se vem afirmando desde a Introdução, Flores da Cunha, situada na antiga região colonial italiana do Rio Grande do Sul (RCI-RS)5. Conde D`Eu (Garibaldi), Dona Isabel (Bento Gonçalves) e Campo dos Bugres (Caxias do Sul) foram as três primeiras colônias italianas no Rio Grande do Sul, fundadas a partir de 1875. Inicialmente, Flores da Cunha se chamava São José e era um distrito de Caxias do Sul. Em 1924, por um decreto estadual, criou-se o município, que tinha por sede a antiga vila de Nova Trento. Em 1935, substituiu-se a denominação Nova Trento por Flores da Cunha, em homenagem ao ex-governador do Estado, José Antônio Flores da Cunha.

Hoje, o município conta com uma população pequena (em torno de 27.000 habitantes $\left.{ }^{6}\right)$, mas não em redução. É vizinho a Caxias do Sul, maior cidade do Rio Grande do Sul após a capital, Porto Alegre. Na área de 272,66 km², a zona rural é relativamente grande e o pequeno centro urbano dá sinais de crescimento. Sua economia é diversificada, inclui indústria, comércio, serviços, agricultura. O

\footnotetext{
5 Sabbatini e Franzina (1977), que empregam termo correspondente (Região de Colonização Italiana), explicam que a RCI-RS corresponde especificamente às áreas das ex-colônias de natureza pública, fundadas entre 1875 e 1892 na Encosta Superior do Nordeste do Rio Grande do Sul. Atualmente, 55 municípios localizam-se nesse território, entre eles Bento Gonçalves, Caxias do Sul, Farroupilha, Flores da Cunha, Garibaldi, São Marcos, Veranópolis, Antônio Prado. De acordo com Frosi e Mioranza (1983) e Frosi (1989), o grupo de imigrantes era misto relativamente à província italiana de origem, sendo quatro as regiões da Itália setentrional de que veio a maioria deles: Lombardia, Vêneto, Fríuli Venezia-Giulia e Trentino-Alto Ádige.

6 Confira os dados do IBGE, censo 2010. Disponíveis em: <www.ibge.gov.br>. Acesso em: 13 mar. 2011.
} 
município é um dos maiores produtores de vinho do Brasil e sua indústria moveleira exporta para a América Latina, Estados Unidos e Europa, principalmente.

Como outros municípios da RCI-RS, Flores da Cunha celebra suas origens em festivais e movimentos culturais, o que reifica a identidade étnica italiana da comunidade.

\section{Figura 1 - Flores da Cunha no Rio Grande do Sul e no Brasil.}
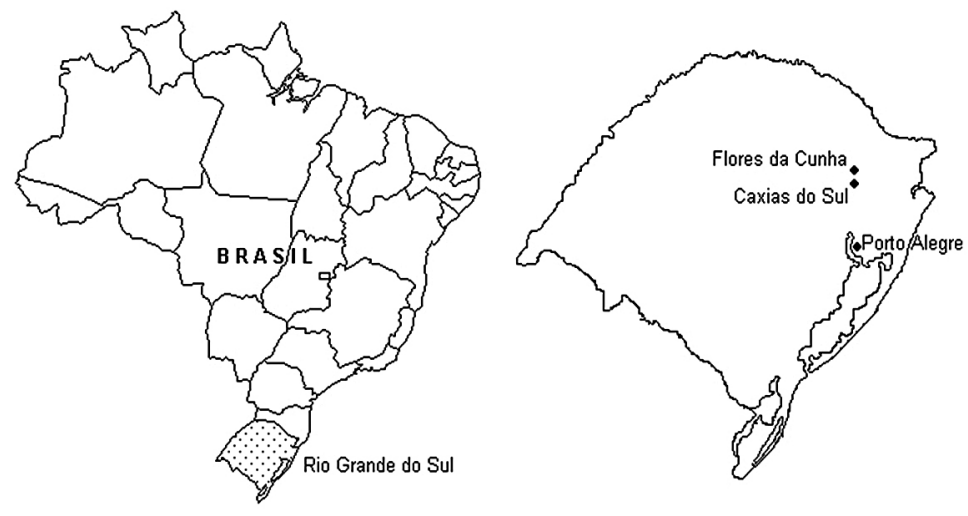

Fonte: Elaboração própria.

\section{A análise de regra variável}

Para a análise de regra variável (LABOV, 1972, 1994, 2001), utilizaram-se 48 entrevistas sociolinguísticas do BDSer com informantes de Flores da Cunha. Essas entrevistas, de que se levantaram os contextos de palatalização, foram realizadas entre 2008 e 2009.

A variável dependente é a palatalização das plosivas alveolares. As variáveis independentes são de dois tipos, linguísticas e extralinguísticas.

As variáveis linguísticas controladas são Contexto Fonológico Precedente, Contexto Fonológico Seguinte, Status da Vogal Alta7 ${ }^{7}$ Posição da Sílaba na Palavra, Tonicidade da Sílaba, Qualidade da Consoante-Alvo. Considerando o que se constatou nos estudos revisados (seção acima), nossas hipóteses foram as de que vogal alta fonológica /i/, sílabas postônicas e átonas e consoante-alvo /t/ condicionariam a palatalização. O papel dos contextos fonológicos precedente e seguinte estaria por ser constatado.

O controle dessa variável tem consequência sobre a ortogonalidade entre grupos de fatores, principalmente os que se referem à tonicidade da sílaba e sua posição na palavra: uma vogal alta fonética é átona, exclusivamente; uma vogal alta fonológica átona praticamente não se verifica em sílaba final de vocábulo. Assim, para viabilizar a operação adequada dos programas do pacote VARBRUL, versão Goldvarb-X, a variável Status da Vogal Alta não foi controlada em rodadas juntamente com as variáveis Posição da Sílaba na Palavra e Tonicidade da Sílaba e vice-versa. 
Os informantes são dos sexos/gêneros masculino e feminino, residentes na zona urbana e rural e estratificados em quatro grupos etários: 18 a 30 anos de idade; 31 a 50 anos; 51 a 70 anos; 71 ou mais anos. Essas características configuram as três variáveis extralinguísticas controladas na análise: Sexo/Gênero, Local de Residência e Faixa Etária. As hipóteses foram as de que falantes do sexo/gênero feminino, idosos e de zona urbana seriam os condicionadores da aplicação da regra.

O Quadro 1 traz o conjunto de variáveis independentes controladas na análise, com exemplos de contextos de palatalização.

\section{Quadro 1 - Variáveis independentes controladas na análise de regra variável.}

\begin{tabular}{|l|l|}
\hline \multicolumn{1}{|c|}{ Linguísticas } & Extralinguísticas \\
\hline Contexto fonológico precedente & Sexo/Gênero \\
Vogal oral: metida, fedido & Feminino \\
Ditongo: oitiva, Neide & Masculino \\
Consoante nasal: mentira, bandido & \\
Consoante lateral: malte, balde & \\
Consoante sibilante: poste, desde & \\
Vibrante ou tepe: arte, morde & \\
Zero: tipo, dia & Faixa etária \\
\hline Contexto fonológico seguinte & $18-30$ anos \\
Vogal: teatro, diabo & $31-50$ anos \\
Consoante sibilante e fricativa anterior: disse, disco, dívida, & $51-70$ anos \\
atiçar, artista, tivesse & 71 ou mais anos \\
Consoante sibilante posterior: tijolo, digital & \\
Consoante oclusiva: tipo, dica & \\
Consoante lateral anterior: dilema, mutilado & \\
Consoante lateral posterior: gatilho, armadilha & \\
Consoante nasal anterior: time, rudimentar, rotina, ladino & \\
Consoante nasal posterior: dinheiro, tinhoso & \\
Vibrante, tepe: tira, direção, Valdir, repartir & \\
Consoante africada: te [dz]isse, se [t]linha & \\
Zero: gente, onde & \\
\hline Status da vogal alta & Local de residência \\
Alta fonológica: mentira, dica & Zona urbana \\
Alta fonética: gente, bonde & \\
\hline Posição da sílaba na palavra & \\
Inicial: teatro, diário & \\
Medial: antigo, ardido & \\
Final: pente, acorde & \\
Monossílabo: diz,TIM & \\
Inicial de locução (clítico): de noite, te queria & \\
Inicial em locução (hospedeiro): pra tirar, se dizer & \\
Monossílabo em locução: se diz, pra ti & \\
\hline Tonicidade da sílaba & \\
Átona não final: atitude, médico & \\
Átona final: vinte, bonde & \\
Tônica: dia. tia & \\
Átona (clítico): de, te & \\
\hline Qualidade da consoante alvo & \\
Vozeada: dia & \\
Desvozeada: tia & \\
\hline
\end{tabular}

Fonte: Elaboração própria. ${ }^{8}$

8 O fator Átona não final reúne pretônicas e postônicas não finais em razão da raridade das últimas na amostra. 
Os contextos levantados das entrevistas foram codificados e posteriormente submetidos aos programas computacionais do pacote VARBRUL, versão Goldvarb $\mathrm{X}^{9}$ para ambiente Windows, que realizam análise estatística de regressão logística.

Os valores obtidos na análise quantitativa são apresentados em percentuais e em pesos relativos. Os percentuais expressam a distribuição dos dados e a aplicação da regra variável por fator dos diferentes grupos (variáveis) controlados. Os pesos relativos expressam a tendência de o processo estudado ocorrer, como efeito dos diferentes fatores considerados na análise. Os pesos relativos estão compreendidos no intervalo de 0 a 1: valores em torno de 0,5 indicam a neutralidade do fator em relação ao processo estudado, valores abaixo de 0,5 indicam que o fator não condiciona (desfavorece) o processo, valores acima de 0,5 indicam que o fator condiciona (favorece) o processo.

\section{A análise da variação linguística como prática social}

Para a análise da palatalização variável como prática social (ECKERT, 2000), realizaram-se análise de rede social e estudo etnográfico.

A análise de rede social considerou os 48 informantes de Flores da Cunha de cujas entrevistas sociolinguísticas levantaram-se os contextos de palatalização considerados na análise de regra variável. A rede foi analisada nas dimensões da estrutura e do conteúdo. Essa última dimensão foi contemplada, como fizeram Blake e Josey (2003), pelo controle dos graus de relacionamento interindividual. As informações consideradas, de natureza cultural e voltadas às práticas, foram obtidas junto aos informantes e complementadas com o conteúdo das entrevistas sociolinguísticas e das fichas sociais dos informantes. Relacionamentos familiares e entre colegas de trabalho são os mais relevantes na comunidade florense, variando neles o grau de intimidade dada a natureza/ frequência da interação. O Quadro 2 traz os graus de relacionamento utilizados na análise: 1, 2 e 3, do mais íntimo ao menos íntimo, em conformidade com os padrões locais.

9 Disponível em: <http://individual.utoronto.ca/tagliamonte/goldvarb.htm>. Acesso em: 21 dez. 2010. 


\section{Quadro 2 - Graus de relacionamento em rede em Flores da Cunha.}

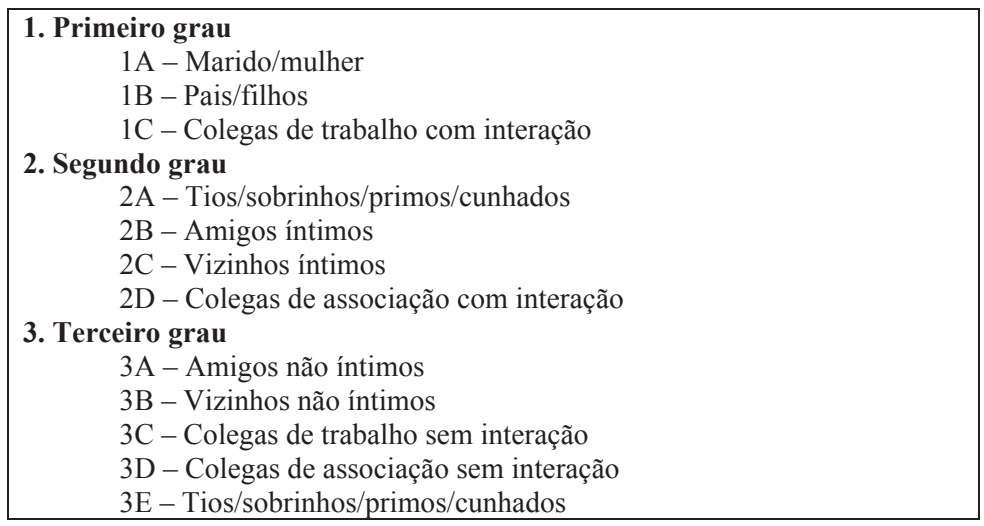

Fonte: Elaboração própria.

A rede social dos informantes foi formada a partir da realização das próprias entrevistas sociolinguísticas, quando um informante indicava outro com as características sociais de interesse ${ }^{10}$. Quando não foi possível obter essa indicação, os pesquisadores, através de seus contatos na comunidade, entrevistaram florenses com o perfil exigido, a eles perguntando, subsequentemente, se conheciam os demais informantes já entrevistados e que espécie de relacionamento mantinham com cada um.

A rede social foi modelada por um grafo (BOAVENTURA NETTO, 1996; FRUCHTERMAN; REINGOLD, 1991; MATHEWS, 1992; GERHARDT; CORSO; LEMKE, 2006). Cada informante é um vértice e cada relação de interação é uma aresta. Efetuou-se um estudo do problema de posicionamento dos vértices de modo que o desenho resultante tivesse bons atributos estéticos e de visibilidade, computacionalmente elaborados, usando-se uma adaptação do algoritmo de Fruchterman e Reingold (1991) e o método de minimização do gradiente. Cruzaram-se, com análise de correlação, a frequência de aplicação individual das realizações variáveis com a aplicação média dos contatos do informante na rede e com características sociais que se mostraram relevantes na análise de regra variável.

No estudo etnográfico, utilizaram-se dois procedimentos: análise crítica de ideologia, de natureza discursiva, e observação participante. Tanto na execução de um quanto na do outro procedimento, a técnica básica é a da inferenciação, como forma de verificar e compreender mudanças sociais ligadas a mudanças linguísticas.

10 O BDSer selecionou os informantes em cada município conforme os critérios Sexo/Gênero (Masculino, Feminino), Faixa Etária (18 a 30 anos; 31 a 50 anos; 51 a 70 anos; 71 ou mais anos), Escolaridade (0 a 4 anos; 5 a 8 anos; 9 a 11 anos; 12 ou mais anos) e Local de Residência (Zona urbana e Zona rural). 
A inferenciação, conforme Spradley (1979), é um processo de aprendizagem realizada pelo pesquisador no convívio com as pessoas, com os grupos pesquisados. São três as grandes fontes de inferências: o que as pessoas dizem, o que elas fazem (suas práticas sociais) e os artefatos que elas usam.

Os resultados referentes à análise crítica de ideologia foram gerados das 48 entrevistas sociolinguísticas de que se levantaram os contextos de palatalização também considerados na análise de regra variável. Seguindo Cerqueira Filho (1982), voltam-se ao que as pessoas dizem, aos assuntos de que falam, reveladores não só das razões tácitas para inovações, inclusive linguísticas, como também de visões de mundo motivadoras de mudanças ou de resistência a elas. Levantamos das entrevistas afirmações das pessoas sobre o que elas fazem diariamente, afirmações ligadas às dimensões do trabalho, da família, do lazer, dos estudos, da religião, da política e da própria comunidade.

Do ponto de vista ideológico e com foco na tensão entre local e global, a hipótese seguida foi a de que, apesar de as elites ${ }^{11}$ regionais tenderem a manter padrões de dominação que não sirvam diretamente à globalização, os padrões locais são cooptados pela globalização, isto é, há dominação sem destruição. Isso corresponderia à tendência à produção da variante não palatalizada (forma tradicional), a despeito das frequências maiores de palatalização em outros falares de português brasileiro.

Outros são dados gerados de momentos de observação participante em festas de capela com almoços ou jantares, feiras, celebrações religiosas como a de Corpus Christi, em que se procurou fazer o que os outros fazem. Assim, observaram-se as ações das pessoas, o protocolo seguido na realização dessas ações, vestimentas, artefatos utilizados.

No que se refere às práticas sociais, nossa hipótese é a de que os florenses em geral, assim como os habitantes de outras comunidades ítalo-brasileiras da região, realizam práticas sociais inovadoras, como a utilização de computadores pessoais e da Internet para comunicação pessoal e para a realização de ações do cotidiano como pagamentos, cadastramentos, matrículas. No entanto não abrem mão de práticas sociais tradicionais: seguem fazendo o mesmo que seus antepassados, por exemplo, ao optar por comer galeto com polenta aos domingos, frequentar missas e outras manifestações religiosas católicas nos finais de semana e em dias santos, visitar parentes nos momentos de lazer e, se habitantes da zona rural, dedicar-se a atividades agrícolas nas pequenas comunidades familiares, atividades essas ligadas ao setor vitivinícola.

11 Sobre a teoria das elites, ver Bottomore (1974) e Mills (1962). 


\section{Resultados}

\section{Análise de regra variável}

Foram 23.163 os contextos de palatalização levantados das entrevistas sociolinguísticas e considerados na análise de regra variável. A proporção total de aplicação da regra foi de 29\%, índice moderado e próximo ao de outros municípios da região, como Antônio Prado (BATTISTI et al. 2007), com 30\%, e Caxias do Sul (MATTÉ, 2009), com 35\%.

Todas as variáveis foram selecionadas após refinamento da análise estatística, com amalgamação de fatores em alguns grupos. Os resultados das variáveis serão apresentados e discutidos pela ordem de relevância estatística dos valores obtidos, da maior para a menor. Destaca-se que, dentre as quatro primeiras variáveis, estão duas linguísticas e duas extralinguísticas, o que revela o caráter tanto estrutural quanto social da palatalização.

O primeiro grupo de fatores selecionado pelo programa na análise dos dados de Flores da Cunha é social e indica variação com mudança em progresso. Trata-se de Faixa Etária, controlado segundo a hipótese de que a palatalização, regra nova na comunidade, estaria em progresso, sendo introduzida pelos mais jovens e por esses difundida aos demais grupos etários. Essa hipótese se confirmou.

Tabela 1 - Aplicação da regra de palatalização e faixa etária.

\begin{tabular}{lclc}
\hline \multicolumn{1}{c}{ Fatores } & Aplic./Total & $\%$ & Peso relativo \\
\hline 18 a 30 anos & $3.114 / 6.146$ & 51 & 0,86 \\
\hline 31 a 50 anos & $1.599 / 5.766$ & 28 & 0,50 \\
\hline 51 a 70 anos & $1.530 / 6.080$ & 25 & 0,42 \\
\hline 71 ou mais anos & $515 / 5.171$ & 10 & 0,14 \\
\hline TOTAL & $6.758 / 23.163$ & 29 & \\
\hline \multicolumn{1}{c}{ Input 0,174} & & \multicolumn{2}{l}{ Significância 0,000}
\end{tabular}

Fonte: Elaboração própria.

O grupo etário mais jovem apresenta a maior proporção de aplicação da regra. Seu peso relativo $(0,86)$ indica não só que os falantes mais jovens condicionam a palatalização mas também que há a tendência de o processo se aplicar e progredir com eles. É o que Bisol (1986) verificou para os descendentes de italianos de Veranópolis e Matté (2009), para os de Caxias do Sul. Mas não é o que Battisti et al. (2007) verificaram em Antônio Prado, onde a palatalização aplica-se numa taxa de 30\%, mas em que há sinais de estabilização do processo em índices modestos. 
Tanto a relação em rede dos informantes de Antônio Prado quanto a orientação positiva dos jovens pradenses explica o fato de a regra, inovadora, não estar progredindo no município, haja vista a estabilização nos grupos de 18 a 30 anos e de 31 a 50 anos. Já em Caxias do Sul e em Flores da Cunha, em que o índice do grupo de 18 a 30 anos aponta o avanço da palatalização, o que há de diferente parece ser uma maior mobilidade territorial dos indivíduos. Há mais oportunidades de contato com pessoas de fora da comunidade, o que abriria a fala a inovações como a palatalização e poderia explicar a tendência ao progresso da regra, a despeito de sua moderada aplicação.

O grupo Status da Vogal Alta contém dois fatores, vogal alta fonológica (mentira) e vogal alta fonética (gente), isto é, vogal alta que pode ser elevada de /e/ átono. Esperava-se encontrar resultados similares aos de Battisti et al. (2007) e Matté (2009), que apontam a vogal alta fonológica como condicionadora da regra. A hipótese foi confirmada, como mostra a Tabela 2.

\section{Tabela 2 - Aplicação da regra de palatalização e status da vogal alta.}

\begin{tabular}{lccc}
\hline \multicolumn{1}{c}{ Fatores } & Aplic./Total & $\%$ & Peso relativo \\
\hline Alta fonológica (mentira) & $5.053 / 8.183$ & 62 & 0,89 \\
\hline Alta fonética (gente) & $1.705 / 14.980$ & 11 & 0,23 \\
\hline TOTAL & $6.758 / 23.163$ & 29 & \\
\hline
\end{tabular}

Input 0,174

Significância 0,000

Fonte: Elaboração própria.

O mais forte condicionador da regra é a própria vogal gatilho, /i/. Os contextos com vogal alta fonológica correspondem a um terço dos dados e a frequência de palatalização neles é alta: $62 \%$. Já nos contextos com vogal /e/ candidata a elevar-se a [i], que reúnem a maioria dos dados, a frequência é baixa, de apenas 11\%. Isso explica a tendência atestada pelos valores de peso relativo obtidos: em Flores da Cunha, a regra tende a aplicar-se com /i/ e a ser inibida por /e/.

Confirma-se a tendência de a vogal alta fonológica condicionar a palatalização e de a vogal alta fonética inibir o processo. Se a elevação de /e/ átono é baixa, não se alimenta a palatalização. E é essa baixa elevação de /e/ átono o que está em jogo em Flores da Cunha. Bisol (1986) atribui a tendência de palatalização com vogal alta fonológica à interação do processo com a variável Etnia, não no que se refere aos aspectos sociais envolvidos, mas a motivações predominantemente internas da variação e mudança, decorrentes do contato do português com o italiano, o alemão e o espanhol, no caso das comunidades por ela estudadas ${ }^{12}$. A autora afirma:

12 As etnias alemã, italiana e fronteiriça, contempladas pela autora, são representadas na amostra por informantes dos municípios gaúchos de Taquara, Veranópolis e Livramento, respectivamente. 
Parece que o contato do dialeto gaúcho com línguas em que a palatalização da oclusiva não existe ou não segue os cânones da Língua Portuguesa [...] vem embargando o caminho de expansão da regra, reforçando-lhe a restrição peculiar nas comunidades monolíngues e acentuando-lhe o caráter de regra adquirida nas comunidades bilíngues. (BISOL, 1986, p.170).

O contato entre português e falares dialetais italianos se verifica ainda hoje na RCI-RS, mesmo que na forma de bilinguismo não generalizado e, em muitos casos, passivo ${ }^{13}$. Africadas como as que resultam da palatalização das plosivas alveolares em português existem nos falares italianos, como nos vocábulos ciao (olá) e oggi (hoje). Mas neles as africadas não são variantes. Além disso, as africadas opõem-se a /t/ e /d/. O que pode transferir-se dos falares italianos ao português é, sim, o reflexo da distinção gramatical veiculada pelas vogais /e/ e /i/ quando morfemas de plural específicos de gênero: -e é morfema feminino plural (donna-donne, mulher-mulheres), -i, morfema masculino plural (bambinobambini, menino-meninos). Falantes bilíngues português-italiano, ou oriundos de comunidades onde ainda se verifica o bilinguismo, tendem a não elevar a média átona /e/, como reflexo de seus hábitos de fala em língua italiana, que requer a clara emissão e manutenção da vogal para garantir a veiculação de informação gramatical. Esse foi o raciocínio de Bisol (1981) no estudo de harmonia vocálica, em que a etnia italiana aparece como a que menos eleva as vogais médias átonas. Entendemos que tal raciocínio também se aplique ao estudo em questão: ainda há bilíngues na comunidade de descendentes de italianos que é Flores da Cunha. A elevação de /e/ átono tende a ser de baixa a moderada no município (ROVEDA, 1998; GUZZO, 2010), o que reduz o número de contextos com vogal alta fonética, que alimentariam a regra de palatalização.

O terceiro grupo selecionado foi Local de Residência. Noll (2008), sobre o português brasileiro, afirma que a palatalização é um processo urbano. É o que verificaram Battisti et al. (2007) em Antônio Prado e que se esperava verificar também em Flores da Cunha. A análise confirmou essa hipótese. Os resultados referentes a Flores da Cunha estão na Tabela 3.

\section{Tabela 3 - Aplicação da regra de palatalização e local de residência.}

\begin{tabular}{lllc}
\hline \multicolumn{1}{c}{ Fatores } & Aplic./Total & $\%$ & Peso relativo \\
\hline Zona urbana & $4.336 / 11.494$ & 38 & 0,67 \\
\hline Zona rural & $2.422 / 11.669$ & 21 & 0,33 \\
\hline TOTAL & $6.758 / 23.163$ & 29 & \\
\hline Input 0,174 & & \multicolumn{2}{c}{ Significância 0,000}
\end{tabular}

Fonte: Elaboração própria.

13 Entende-se por bilinguismo passivo o de indivíduos que apenas compreendem uma das línguas, não falam, não escrevem, tampouco leem essa língua, que é não dominante. 
A frequência de palatalização, embora moderada na zona urbana (38\%), é superior à verificada na zona rural (21\%). Os pesos relativos obtidos indicam que o processo tende a aplicar-se na zona urbana de Flores da Cunha, favorecedora da regra, e é inibido na zona rural. Essa é a tendência também em Antônio Prado e em Caxias do Sul.

A razão para esse comportamento distinto e polarizado dos dois locais de residência pode ter relação, como já observaram Battisti et al. (2007) em Antônio Prado, com práticas sociais distintas realizadas pelos indivíduos e com a rede social que integram. As zonas rurais de municípios da RCI-RS abrigam pequenas propriedades rurais produtivas, quase autossuficientes e geridas por um núcleo familiar que trabalha e vive na terra. Afora os integrantes mais jovens da família, que se deslocam diariamente a escolas próximas para estudar, os demais membros apresentam pequena mobilidade territorial e, assim, travam contato com poucos desconhecidos. Sendo a palatalização aspecto inovador na fala em língua portuguesa, mas cuja difusão depende de contato interpessoal e de práticas compartilhadas, é de se esperar que a alternante palatalizada tenha pequeno emprego, pois os indivíduos da zona rural expõem-se pouco a indivíduos palatalizadores, a interação entre eles é quase nula. As redes sociais que formam são densas e multiplexas, impedindo a palatalização de nelas entrar e se propagar.

Outro aspecto que merece destaque é o fato de o bilinguismo portuguêsitaliano persistir na zona rural. Pelas razões abordadas acima quando da apresentação dos resultados da variável Status da Vogal Alta, esse contato preserva da elevação a vogal média que desencadearia a palatalização e que representa boa parte dos contextos analisados.

Os habitantes da zona urbana realizam práticas sociais diferenciadas, o que contribui para a difusão da regra. Tanto o setor de comércio quanto o da indústria e o de serviços propiciam interação com indivíduos de municípios vizinhos e, mais importante, de fora da RCI-RS. O próprio deslocamento para realizar curso superior leva, principalmente os jovens, a práticas compartilhadas com indivíduos diversos, flexibilizando laços que preveniriam mudanças de comportamento, inclusive o linguístico.

No quarto grupo de fatores selecionado, Qualidade da Consoante-Alvo, controlou-se a consoante candidata à palatalização, se a vozeada /d/ ou a desvozeada /t/. A hipótese era a de que em Flores da Cunha a consoante /t/ condicionaria a regra de palatalização, como visto em Battisti et al. (2007) e Matté (2009) para Antônio Prado e Caxias do Sul, respectivamente. Novamente, a hipótese foi confirmada pela análise. Os resultados de Flores da Cunha estão na Tabela 4. 


\section{Tabela 4 - Aplicação da regra de palatalização \\ e qualidade da consoante-alvo.}

\begin{tabular}{lllc}
\hline \multicolumn{1}{c}{ Fatores } & Aplic./Total & $\%$ & Peso relativo \\
\hline Desvozeada (tia) & $3.817 / 10.573$ & 36 & 0,60 \\
\hline Vozeada $($ dia $)$ & $2.941 / 12.588$ & 23 & 0,40 \\
\hline TOTAL & $6.758 / 23.163$ & 29 & \\
\hline
\end{tabular}

Input 0,174

Significância 0,000

Fonte: Elaboração própria.

A frequência de palatalização de /t/ (36\%) não é tão distinta da palatalização de /d/ (23\%). No entanto os pesos relativos são reveladores: contextos com /t/ tendem a ser palatalizados; já a consoante vozeada /d/ desfavorece o processo. A mesma tendência se verifica nos outros municípios, o que, retomando a hipótese de Guy (2000), se pode esperar de condicionamentos de natureza interna ou estrutural que reflitam a unidade maior do português do Brasil. A explicação para o fato pode ser a de Dutra (2007, p.105-106):

[...] durante a articulação de consoantes [-voz], a energia articulatória se concentra nos órgãos supraglóticos [...] o processo de palatalização leva a uma grande concentração de energia na parte anterior da cavidade bucal e é justamente a articulação das consoantes [-voz] que propicia tal configuração articulatória.

Há, portanto, uma semelhança na articulação da consoante desvozeada /t/ que a aproxima do processo de palatalização, explicando seu papel favorecedor.

Os demais grupos de fatores não foram descartados da análise estatística durante as rodadas dos programas computacionais, mas os valores obtidos ou giram em torno do ponto neutro, caso em que se atesta a ausência de papel da variável frente ao processo investigado, ou apresentam enviesamento na relação entre frequências e pesos relativos ${ }^{14}$. Por essa razão, a exposição dos resultados segue obedecendo a ordem de relevância estatística, mas a discussão será breve.

14 Enviesamentos ocorrem quando os maiores pesos não correspondem às maiores frequências e vice-versa. 


\section{Tabela 5 - Aplicação da regra de palatalização e posição da sílaba na palavra.}

\begin{tabular}{cccc}
\hline Posição da sílaba na palavra & Aplic./Total & $\%$ & Peso relativo \\
\hline Final (pente) & $1.416 / 8.321$ & 17 & 0,54 \\
\hline $\begin{array}{c}\text { Inicial de locução (de noite) } \\
\text { Inicial/inicial em locução (teatro, de } \\
\text { teatro) }\end{array}$ & $390 / 4.743$ & 8 & 0,50 \\
\hline $\begin{array}{c}\text { Medial (antigo) } \\
\text { Monossílabo/monossílabo em } \\
\text { locução (diz) }\end{array}$ & $1.843 / 3.361$ & 55 & 0,47 \\
\hline TOTAL & $81 / 221$ & 37 & 0,46 \\
\hline Input 0,174 & $6.758 / 23.163$ & 29 \\
\hline
\end{tabular}

Fonte: Elaboração própria.

O maior peso relativo é o do fator Final, ainda assim em torno do ponto neutro. Além disso, há enviesamentos nos resultados. Como afirmamos na nota 7, fatores da variável Status da Vogal Alta se sobrepõem aos da variável Posição da Sílaba na Palavra como também aos de Tonicidade. O Gráfico 1 traz o cruzamento de Status da Vogal com Posição e talvez explique os resultados desse último grupo de fatores.

\section{Gráfico 1 - Palatalização por Status da Vogal Alta x Posição da Sílaba na Palavra.}

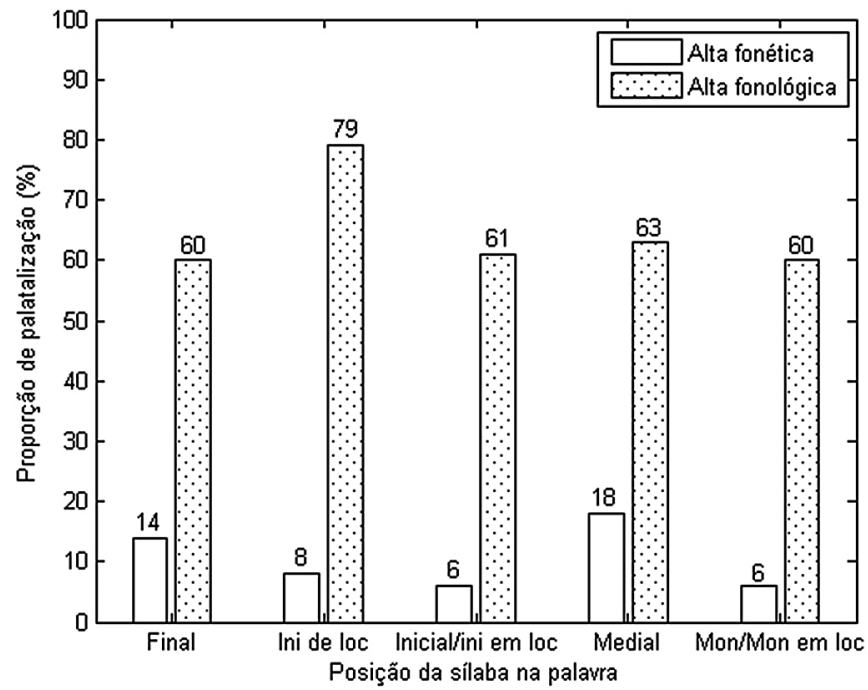

Fonte: Elaboração própria. 
Todos os fatores considerados combinam-se e em todas as posições a palatalização é desencadeada por vogal alta fonológica. Praticamente não há diferença de aplicação entre as posições. É, portanto, o efeito do status da vogal, e não propriamente a posição da sílaba na palavra, o que conta para a palatalização.

A Tabela 6 traz os resultados da variável Contexto Fonológico Seguinte. Enviesamentos se verificaram novamente, mas há ao menos um valor de peso relativo que se destaca, o do fator Vogal Oral, que condiciona a aplicação da regra.

\section{Tabela 6 - Aplicação da regra de palatalização e contexto fonológico seguinte.}

\begin{tabular}{cccc}
\hline Fatores & Aplic./Total & $\%$ & Peso relativo \\
\hline Vogal oral (teatro) & $1.115 / 2.552$ & 44 & 0,59 \\
\hline Zero (gente) & $1.216 / 7.884$ & 15 & 0,53 \\
\hline $\begin{array}{c}\text { Consoante sibilante/fricativa } \\
(\text { disco/tive })\end{array}$ & $1.426 / 4.188$ & 34 & 0,50 \\
\hline $\begin{array}{c}\text { Consoante oclusiva/africada } \\
(\text { ditado, de[d]/inho) }\end{array}$ & $1.147 / 4.119$ & 28 & 0,45 \\
\hline $\begin{array}{c}\text { Consoante nasal/líquida } \\
(\text { tinh } \text {, diretora })\end{array}$ & $1.854 / 4.420$ & 42 & 0,45 \\
\hline TOTAL & $6.758 / 23.163$ & 29 \\
\hline Input 0,174 & \multicolumn{3}{c}{ Significância 0,000}
\end{tabular}

Fonte: Elaboração própria.

Os demais fatores da variável Contexto Fonológico Seguinte, com pesos relativos em torno do ponto neutro, não têm papel atuante.

O controle estatístico não sugeriu descartar a variávelTonicidade, mas também aqui os resultados não são expressivos, todos os pesos relativos aproximam-se do ponto neutro. Veja-se a Tabela 7:

\section{Tabela 7 - Aplicação da regra de palatalização e tonicidade.}

\begin{tabular}{cccc}
\hline Tonicidade da sílaba & Aplic./Total & $\%$ & Peso relativo \\
\hline Tônica $($ dia $)$ & $3.004 / 4.768$ & 63 & 0,53 \\
\hline Átona não final $($ atirado, médico $)$ & $2.104 / 5.452$ & 39 & 0,52 \\
\hline Átona: clítico $($ de, te $)$ & $400 / 4.849$ & 8 & 0,49 \\
\hline Átona final: $($ vinte $)$ & $1.250 / 8.094$ & 15 & 0,47 \\
\hline TOTAL & $6.758 / 23.163$ & 29 \\
\hline Input 0,174 & \multicolumn{3}{c}{ Significância 0,000}
\end{tabular}

Fonte: Elaboração própria.

O cruzamento da variável Tonicidade com Posição da Sílaba na Palavra sugere a razão dessa inexpressividade, como se vê no Gráfico 2: 


\section{Gráfico 2 - Palatalização por Tonicidade x Posição da Sílaba na Palavra.}

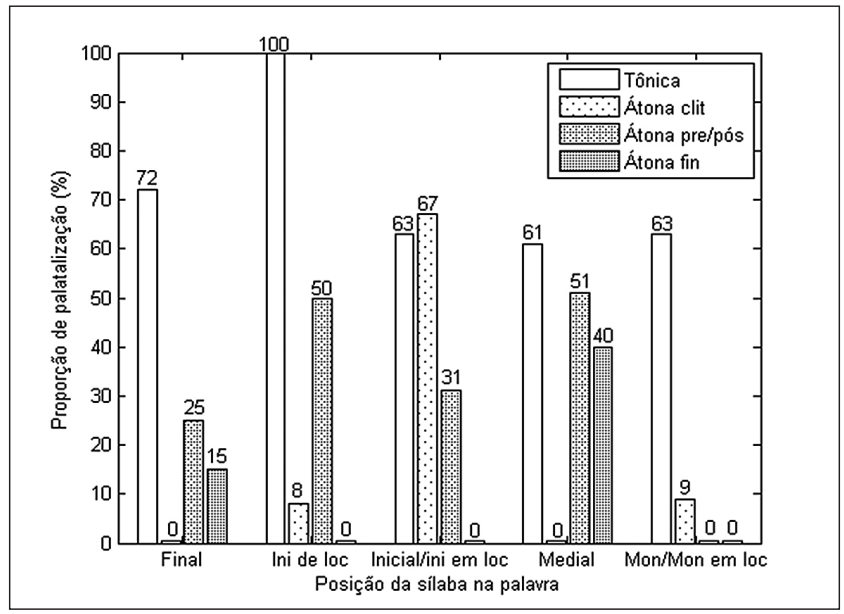

Fonte: Elaboração própria.

O Gráfico 2 permite visualizar a inexistência de combinação de certos fatores: não poderia haver sílaba átona final a não ser na posição final da palavra; de forma complementar, as demais sílabas átonas ocupam as outras posições. Apenas a sílaba tônica ocupa todas as posições da palavra. Vale observar que a frequência de palatalização em sílaba tônica mantém-se significativa, independentemente da posição que ocupa na palavra. Mostra-se condicionadora da palatalização a Tonicidade da Sílaba, antes que Posição da Sílaba na Palavra.

Pelo número insuficiente de dados em alguns fatores da variável Contexto Fonológico Precedente, como também por enviesamentos entre frequências e pesos relativos, verificados na primeira rodada e em outras subsequentes, fizeramse amalgamações, de que resultaram os quatro fatores registrados na Tabela 8.

Tabela 8 - Aplicação da regra de palatalização e contexto fonológico precedente.

\begin{tabular}{cccc}
\hline Fatores & Aplic./Total & $\%$ & Peso relativo \\
\hline Consoante sibilante (poste) & $310 / 641$ & 48 & 0,56 \\
\hline $\begin{array}{c}\text { Vogal oral/ditongo } \\
(\text { cedido, leite) }\end{array}$ & $1.446 / 4.376$ & 33 & 0,54 \\
\hline Zero (tipo) & $3.398 / 11.088$ & 31 & 0,49 \\
\hline $\begin{array}{c}\text { Consoante lateral/vibrante/nasal } \\
\text { (malte, parte, } \text { mentira })\end{array}$ & $1.604 / 7.058$ & 23 & 0,48 \\
\hline TOTAL & $6.758 / 23.163$ & 29 & Significância 0,000
\end{tabular}

Fonte: Elaboração própria. 
O fator Consoante Sibilante aparece como condicionador da regra, com peso relativo de 0,56, mas o número total de contextos para esse fator não é significativo do ponto de vista estatístico ${ }^{15}$. Os pesos relativos dos demais fatores agrupam-se em torno do ponto neutro.

A variável Sexo/Gênero, embora não descartada na análise estatística, ocupa a última posição na ordem de relevância dos grupos de fatores. As proporções de aplicação, de $29 \%$ para cada sexo/gênero, e a neutralidade dos fatores indicada pelos pesos relativos, em torno de 0,50, permitem-nos afirmar que sexo/gênero não tem papel destacado na palatalização das plosivas alveolares em Flores da Cunha.

Tabela 9 - Aplicação da regra de palatalização e sexo/gênero.

\begin{tabular}{|c|c|c|c|}
\hline Fatores & Aplic./Total & $\%$ & Peso relativo \\
\hline Masculino & $3.348 / 11.361$ & 29 & 0,53 \\
\hline Feminino & $3.410 / 11.802$ & 29 & 0,47 \\
\hline TOTAL & $6.758 / 23.163$ & 29 & \\
\hline
\end{tabular}

Fonte: Elaboração própria.

A análise de regra variável da palatalização das plosivas alveolares em Flores da Cunha permite afirmar que o processo é condicionado pelos jovens, por vogal alta fonológica, por habitantes da zona urbana do município e por consoante-alvo desvozeada. Aos fatores das demais variáveis controladas não é possível atribuir papel claro, embora os resultados tenham demonstrado que exerçam algum efeito.

A análise de rede social dos informantes permitirá abordar por outro ângulo, o das práticas sociais, a correlação de jovens e habitantes urbanos com a palatalização. O conteúdo das entrevistas sociolinguísticas e o que se observou na participação em práticas da comunidade também contribuirão para essa abordagem.

\section{A palatalização variável como prática social}

\section{Análise de rede}

A rede social dos informantes de Flores da Cunha é densa e nela predominam os relacionamentos de terceiro grau. A Figura 2 traz a configuração da rede.

15 Não reúne o mínimo de 10\% do total de dados da análise. 
Os informantes são representados por retângulos contendo o seu número de identificação no BDSer. O relacionamento entre dois informantes é representado por uma linha unindo os retângulos, e os graus de relacionamento, por diferentes linhas: relacionamentos de primeiro grau são representados por uma linha contínua mais grossa; os de segundo grau, por uma linha contínua mais fina, e os de terceiro, por uma linha tracejada.

\section{Figura 2 - Rede social dos informantes de Flores da Cunha. Rede FC: Número do informante}

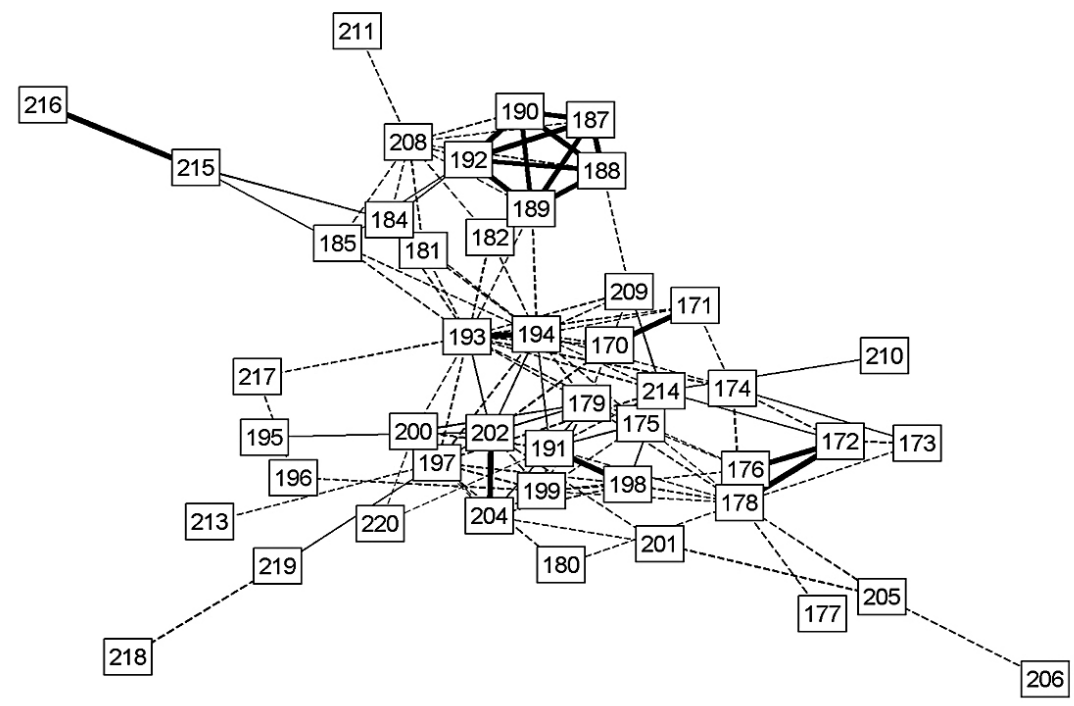

Fonte: Elaboração própria.

A rede possui 48 informantes ligados por 121 contatos. A proporção de conexão é de 0,1169 e está associada à densidade da rede social. Pode ser entendida como a probabilidade de que, escolhidos ao acaso, dois informantes tenham contato. A rede social dos informantes de Flores da Cunha é densa, com uma média de 5,26 contatos por informante. Alguns informantes, como os informantes 206, 211, 216 e 218, possuem contato com apenas um outro informante na rede. Outros informantes, como o 193 e o 194, apresentam contatos com muitos informantes da rede: 16 e 17 contatos, respectivamente. São elementos centrais na rede. Foram os primeiros contatos na comunidade e serviram de ponte para novos contatos na pesquisa.

A Figura 3 mostra a rede social de Flores da Cunha com o registro, nos retângulos, da proporção de aplicação da palatalização de cada informante. 


\section{Figura 3 - Rede social de Flores da Cunha: proporção de aplicação da regra variável.}

Rede FC: Proporção de aplicação RV

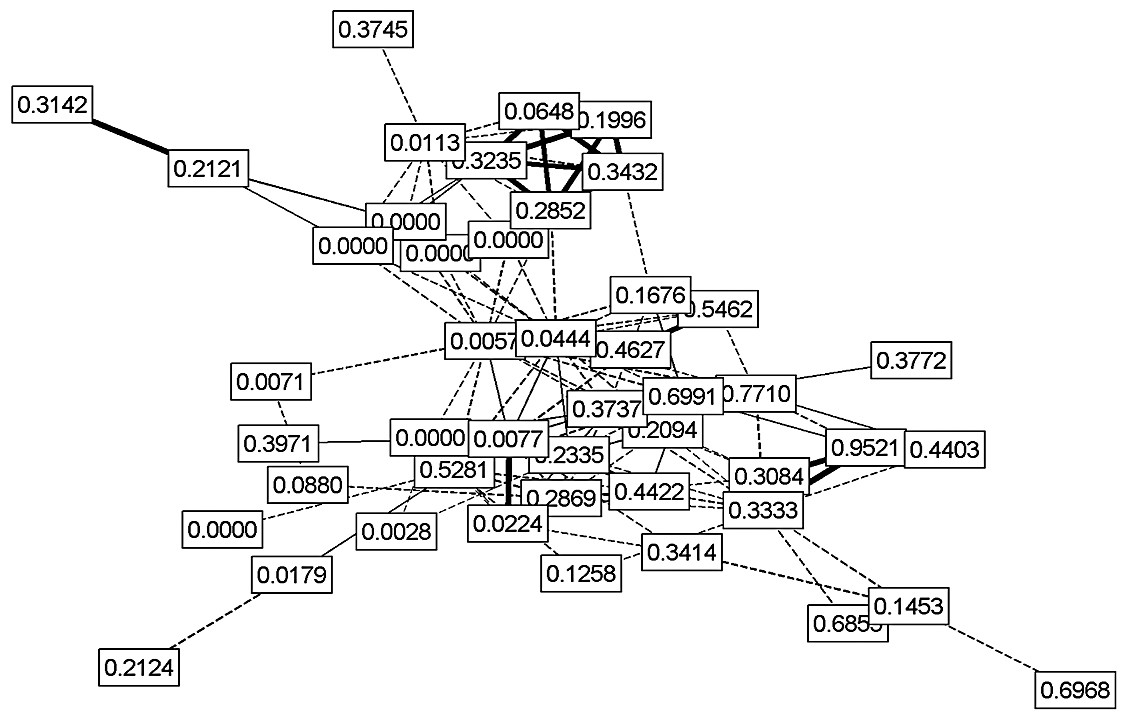

Fonte: Elaboração própria.

Correlacionadas a proporção de aplicação de um dado informante e a proporção de aplicação de seus contatos, verificou-se que os relacionamentos em rede têm efeito sobre o comportamento linguístico: sujeitos palatalizadores relacionam-se predominantemente com sujeitos palatalizadores e vice-versa. A Figura 4 representa, num diagrama de dispersão, essa correlação. Cada ponto representa um par de informantes. A forma do ponto representa o grau de relacionamento entre os informantes, conforme a legenda. Observa-se uma leve, porém significativa, correlação positiva $(0,1920<\mathrm{r}<0,2129 ; 0,0044<$ sig. $<$ 0,0105) ${ }^{16}$ entre as proporções de aplicação dos informantes.

16 O coeficiente de correlação foi calculado levando em consideração o grau de relacionamento: pesos 3, 2 e 1 para graus de relacionamento 1,2 e 3, respectivamente. O coeficiente de correlação foi calculado 1.000 vezes, alternando-se aleatoriamente os informantes 1 e 2 em cada relacionamento. Esse procedimento fez com que os valores do coeficiente de correlação e significância variassem. Os valores de r e sig. correspondem a um intervalo de confiança de 95\%, seguindo um procedimento bootstrap. 
Figura 4 - Proporção de aplicação de um dado informante

e a proporção de aplicação de seus contatos.

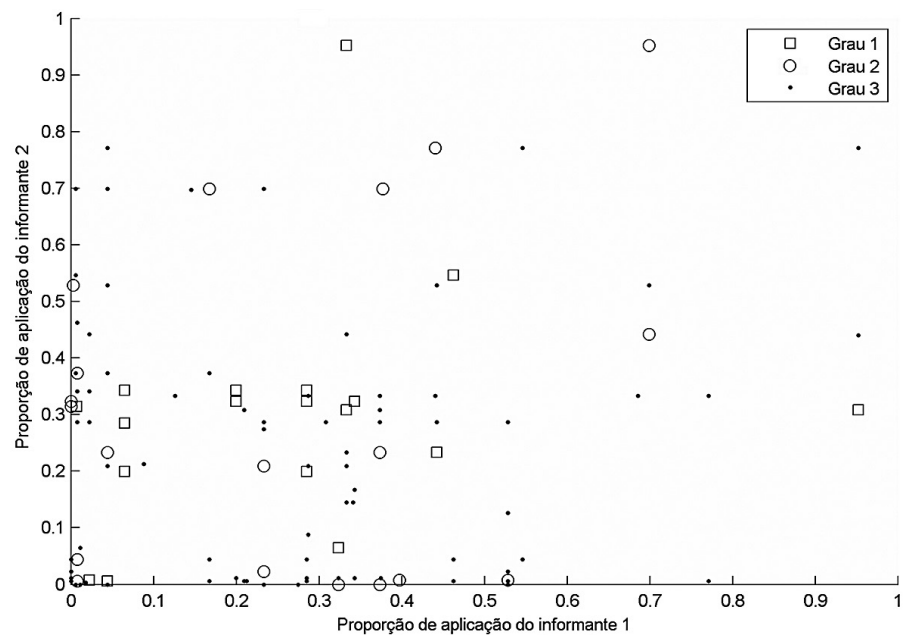

Fonte: Elaboração própria.

A Figura 5 mostra a rede social de Flores da Cunha com o registro da idade de cada informante. A Figura 6 mostra a rede social de Flores da Cunha com o local de residência dos informantes (U para urbano, $R$ para rural).

Em relação à idade (Figura 5), chama a atenção o fato de não se visualizarem, na rede, aglomerações de sujeitos de um mesmo grupo etário.

Figura 5 - Rede social de Flores da Cunha: idade. Rede FC: Idade

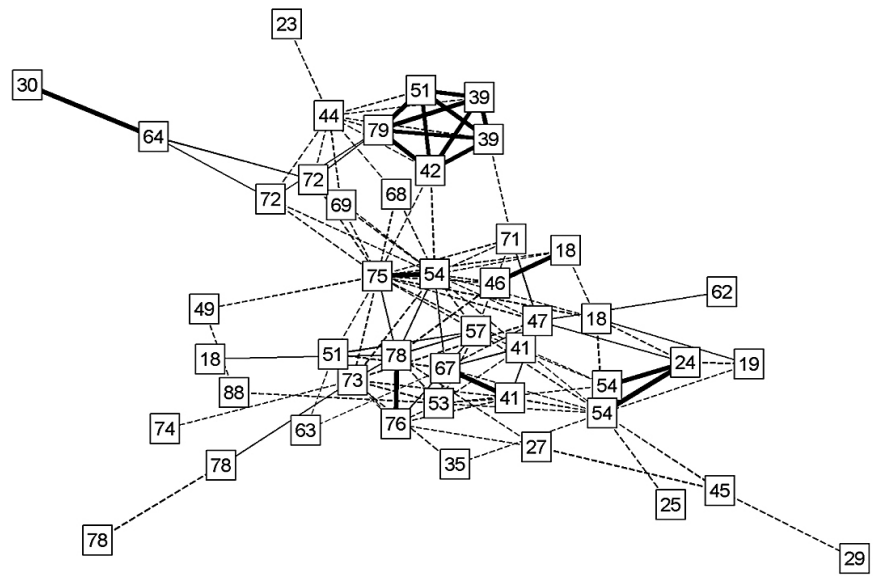

Fonte: Elaboração própria. 


\section{Figura 6 - Rede social de Flores da Cunha: local de residência.}

Rede FC: Local de residência

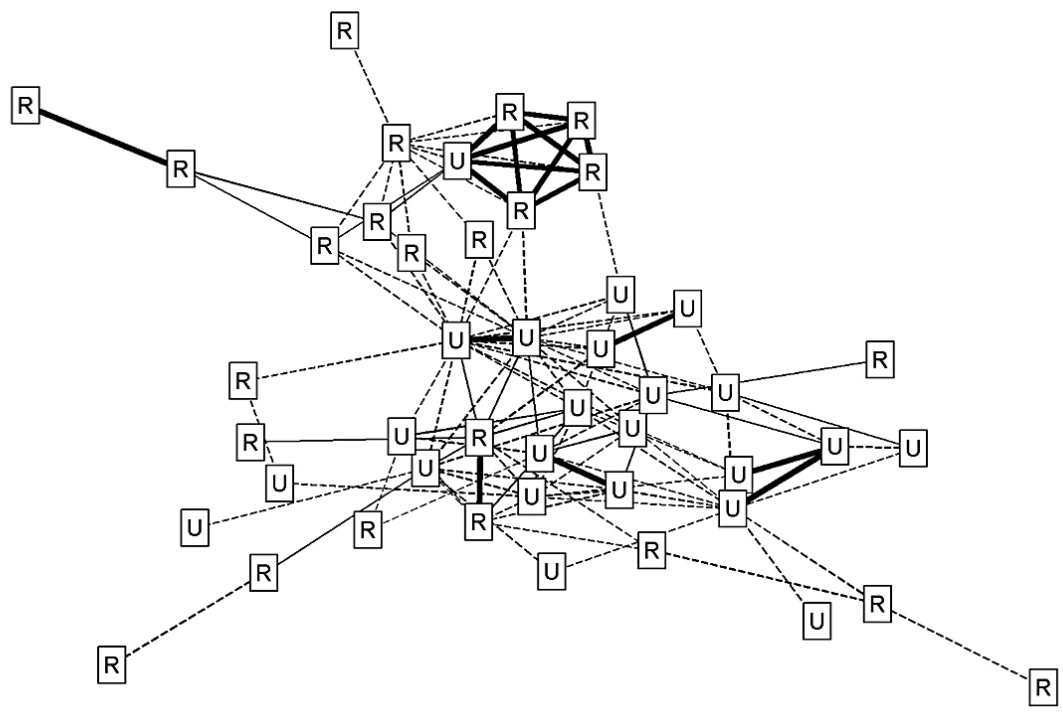

Fonte: Elaboração própria.

Sujeitos situados nos quatro grupos etários na análise de regra variável antes realizada não se relacionam exclusivamente com sujeitos do mesmo grupo etário. Em muitos casos, há relacionamentos familiares em jogo: de pais e filhos, tios, sobrinhos, avós e netos, como também de vizinhos e colegas de trabalhos de variadas idades, o que contribui para a ausência de aglomerações por similaridade etária. Relevante é o fato de os jovens, que condicionam a palatalização, situarem-se na periferia da rede, posição em que os efeitos de seu comportamento não são tão fortes como poderiam ser se ocupassem uma posição central na rede.

Quanto ao local de residência (Figura 6), são visíveis as aglomerações: sujeitos de zona urbana relacionam-se predominantemente com sujeitos de zona urbana e vice-versa. Os laços mais fortes, os de relacionamentos de primeiro grau, estabelecem-se na mesma zona; os mais fracos, de terceiro grau, ultrapassam os locais de residência. Isso sustenta a ideia de que as práticas sociais diárias em Flores da Cunha são localizadas. A mobilidade territorial não é acompanhada de relacionamentos fortes, que poderiam ter efeitos sobre o comportamento verbal dos sujeitos. Especialmente na zona rural, o trabalho na terra requer a permanência no local, o que não fomenta inovações. 


\section{Análise das entrevistas e observação participante}

Os relatos dos entrevistados de Flores da Cunha sobre seu cotidiano repetem o que já se havia verificado em Antônio Prado, também situado na RCI-RS. Neles, há indícios de que a comunidade, embora não tenha aberto mão de práticas sociais tradicionais, ligadas à história da imigração italiana, abre-se a práticas inovadoras, o que se faz presente sobretudo na fala dos jovens. Por exemplo, considerem-se as faixas etárias usadas na análise quantitativa (18 a 30 anos, 31 a 50 anos, 51 a 70 anos e 71 ou mais anos). Quando os entrevistados falam sobre lazer, o peso dos meios de comunicação de massa é maior na fala dos entrevistados jovens e da faixa de 31 a 50 anos, diminuindo nas demais faixas etárias. Assistir a filmes no cinema e usar computador com acesso à Internet é mais frequente entre os jovens, principalmente os da zona urbana que se deslocam a outras comunidades para realizar estudos em nível médio e superior. Informantes de todas as faixas etárias assistem a programas de televisão e ouvem rádio. Todos afirmam ler, muda o tipo de texto lido: os mais jovens afirmam ler livros, os demais leem jornais e revistas, usualmente.

Percebe-se a importância da família como referência para as práticas do trabalho e, de variadas maneiras, para os momentos de lazer. Todos os informantes, se não afirmam textualmente que gostam do que fazem, dão a entender isso. Até os jovens urbanos, aqueles que têm maior trânsito fora dos limites de Flores da Cunha e relatam não haver na cidade shopping, teatro e cinema para frequentar, passam momentos agradáveis com amigos e familiares nos finais de semana, com quem praticam esportes e têm contato com a natureza.

Em se tratando dos jovens, que condicionam a palatalização e, assim, podem ser tomados como inovadores, a observação participante revela uma tendência similar: inovação com preservação. Percebemos nos jovens florenses os jeans, tênis, jaquetas, bonés e celulares que acompanhariam os jovens em qualquer outro lugar do Rio Grande do Sul e do Brasil. Um pouco mais cuidados e "arrumadinhos", é verdade, mas todos esses itens estão lá, no visual dos jovens, numa demonstração de que a prática é local, mas os artefatos são supralocais.

Os informantes são católicos em sua grande maioria. Entre os grupos mais jovens (18 a 30 anos e 31 a 50 anos), apesar da afirmação, na entrevista, de que não são praticantes, observa-se algum envolvimento em práticas religiosas, principalmente as festivas. Na celebração de Corpus Christi, por exemplo, que envolve uma missa na igreja matriz e, em seguida, a procissão do Senhor Morto sobre tapetes de serragem, constatamos a presença de número significativo de jovens. Não pareciam estar lá forçados, sua participação demonstrou-se fervorosa. Constatamos também que muitos tapetes haviam sido confeccionados por grupos de jovens juventude católica, escoteiros, organizações antidrogas, grêmios desportivos. 
Identificadas com o tradicional, as práticas religiosas são o exemplo claro de elemento local que faz parte da representação da relação imaginária que os indivíduos mantêm com suas condições de existência, que é assim componente da identidade construída na comunidade, mas que tem sua força minimizada por elementos não locais. É em cenários como esse que o novo, o não tradicional, entra, embora não com muita liberdade ou intensidade.

Talvez reforçada pelas festas locais e pelo turismo, que celebra e comercializa as raízes italianas, há uma consciência étnica que serve de explicação, para o próprio jovem, da razão de realizar certas práticas, como se pode captar de uma afirmação assim:

[...] a maioria (dos jovens) aqui da cidade tem descendência italiana. (Tu) sabe que descendência italiana sempre tem a matriarca e o patriarca. Eu acho que a maioria sai, assim, bastante "família" e sempre tem que jantar junto com o pai e com a mãe, salvo exceções. [...] Chega essa idade assim e "ah, tenho que casar, tenho que ter minha família". (Inf.172, 24 anos, masculino, zona urbana).

A vida em família não parece ser algo que o jovem gostaria de evitar, tampouco um real desejo seu, mas algo que acontece com ele. O jovem florense nem se rebela contra a família nem adere incondicionalmente a ela, o que pode estar na base das graduais e pequenas mudanças diárias por ele promovidas, embora as tradições sejam seguidas, inclusive nos momentos de lazer:

Aqui (se) segue... um pouco de tradição da cidade, que no caso é, no domingo, sair e dar voltas ao redor da praça. É uma coisa que a cidade pequena tem. Ficar parado olhando o movimento passar. (Inf.172, 24 anos, masculino, zona urbana).

Essa fala não revela propriamente uma opção do jovem, mas uma consequência das tradições e, mais importante, do fato de a cidade não oferecer opções de lazer, comentário que soa como queixa na fala de muitos deles e que é razão para buscarem, em outras cidades, diferentes formas de distração:

Eu gostaria de viver em Caxias... Acho que desde pequena... uma vez eu fui na Festa da Uva lá e nossa!... sempre gostei de Caxias, tanto pequena quanto adolescente, sempre quis ir pra Caxias, mas minha mãe não deixava e, nossa... eu ia no cinema, ficava feliz, sempre gostei da cidade. (Inf.174, 18 anos, feminino, zona urbana).

Deslocar-se a outras localidades, dessa forma, parece fazer parte de ser jovem em Flores da Cunha, inclusive para cursar faculdade (não há instituição de Ensino Superior em Flores da Cunha), mas em um roteiro de ida e volta: o jovem realiza 
práticas fora da comunidade e retorna a Flores da Cunha. Em termos linguísticos, tem contato com outros padrões de fala e pode, nessa circunstância, sentir-se pressionado a evitar formas reveladoras de sua identidade local, como empregar formas não palatalizadas. É possível então que, buscando sintonia com a fala do outro, abra mão momentaneamente de marcas locais e palatalize as plosivas alveolares. Depois, esse mesmo jovem retorna a Flores da Cunha e, lá, volta a orientar-se pela identidade e pelos valores locais, embora não realize práticas sociais exatamente da mesma forma que os florenses mais velhos. Sobre sair da comunidade e retornar a ela, e também sobre mudanças geracionais, observe-se a afirmação de outra jovem sobre trabalho:

A gurizada daqui não quer mais trabalhar na colônia [...]Vão pra Caxias estudar. Todos fazem faculdade, a grande maioria. Aí, então, ninguém mais quer trabalhar na colônia como acontecia antigamente, as famílias eram numerosas, as pessoas ficavam na colônia e não estudavam, né [...] Eu acho que mais pessoas continuam morando aqui e vão e voltam, do que se mudam. São poucos que se mudam. (Inf.211, 23 anos, feminino, zona rural).

A jovem começa afirmando que "a gurizada" não quer mais trabalhar na terra, nas propriedades rurais, junto à família. A suposição imediata seria a de que os jovens da zona rural desejariam migrar para a cidade, mas não é o que vai na última afirmação da jovem, repetida a seguir: "Eu acho que mais pessoas continuam morando aqui e vão e voltam, do que se mudam. São poucos que se mudam". É o tipo de trabalho que jovens de zona rural criticam: muito duro, segundo alguns. Mas não criticam o lugar onde moram, que não abandonam, se possível. É o que observamos em campo. Nas propriedades rurais onde se cultiva uva, por exemplo - setor bastante lucrativo para os pequenos proprietários rurais da região -, jovens que, na adolescência, planejaram abandonar a zona rural afirmam ter se dado conta, alguns anos depois, de que a viticultura lhes daria um retorno financeiro interessante. E de fato trabalham na terra, acompanhando seus pais.

Sobre práticas linguísticas e o valor das formas alternantes, são raras as afirmações nas entrevistas sociolinguísticas, como é de se esperar. Mas veja-se uma interessante, de uma jovem que falava sobre padrões familiares:

Assim: começa sempre pelos avós, então, a criação dos meus tios, né, era uma e veio vindo... e a gente sempre pegava [...] o próprio falar: tu fala "erado", e quem convive contigo que fala "erado" vai falar sempre "erado". (Inf.171, 18 anos, feminino, zona urbana).

A jovem tem ciência de que, ao falarmos, tendemos a reproduzir práticas linguísticas. Ela seleciona uma alternante, o emprego de vibrante simples em lugar de múltipla, saliente para muitos florenses e para "os de fora" da comunidade, e 
deixa transparecer que há algo de negativo que a acompanha. A jovem entende o emprego de vibrante simples como um erro que se poderia ou deveria evitar. Não é o mesmo o que ocorre com as formas palatalizadas. Um exemplo disso é o que vem a seguir. Em campo, após realizarmos uma entrevista sociolinguística com uma florense de zona rural do grupo etário de 51 a 70 anos, essa conta-nos que sua neta mais velha cursa Direito na universidade do município vizinho. A outra neta, de apenas oito anos de idade e que ouvia a conversa, corrige nossa réplica, em função de uma forma palatalizada:

- "... e a minha neta faz Direito [sem palatalização] em Caxias", diz a entrevistada.

- "[Dj]ireito [com palatalização]? Que legal, bem importante", replica a entrevistadora.

- "Não é [Dj]ireito, é Direito [com ênfase nas sílabas iniciais]", corrige a neta.

O que pode ter originado essa correção? Lições de não palatalização não há na escola, a menina não teria reproduzido ali um ajuste aprendido em aulas de Língua Portuguesa. A forma palatalizada é, sem dúvida, saliente para a menina. Interpretamos a correção como uma solicitação de ajuste ao comportamento linguístico local, como um depoimento de que "não se fala assim aqui". A variante palatalizada não é um erro com sanções sociais, mas uma forma pouco frequente ou quase inexistente nas interações cotidianas da menina com os seus e, quem sabe, nas interações de muitos outros florenses. As formas palatalizadas são entendidas como não locais e seu prestígio é relativo ao grupo social a que pertence o florense (rural ou urbano) e à situação de uso da linguagem (se entre florenses, ou entre florenses e não locais).

Em termos de práticas sociais e cultura local, então, vimos, com o estudo etnográfico, indícios de um hibridismo em que aspectos tradicionais e inovadores convivem, em que mudanças linguísticas (entre outras) ocorrem, mas lentamente.

\section{Conclusão}

A palatalização variável das plosivas alveolares, processo inovador no português falado em Flores da Cunha, foi analisada quantitativa e qualitativamente. Verificou-se que a palatalização tem condicionamento linguístico e social e produz formas salientes aos florenses, valoradas conforme suas práticas sociais locais.

A vogal alta fonológica condiciona a palatalização, a vogal alta fonética inibe o processo, porque a elevação de /e/ átono é baixa em Flores da Cunha, o que não alimenta a palatalização. Outro condicionador linguístico é a consoante- 
alvo desvozeada /t/, cuja articulação concentra energia na parte anterior da cavidade bucal, à semelhança do processo de palatalização. Os condicionadores sociais são jovens e habitantes da zona urbana, sujeitos cujas práticas sociais de lazer, estudo e trabalho misturam elementos locais e não locais, expondoos a grupos palatalizadores de outras comunidades e, assim, tornando sua fala porosa a mudanças.

A densidade da relação em rede dos informantes e o papel central que nele ocupam os sujeitos dos grupos etários mais velhos explicam por que a palatalização, introduzida no grupo pelos mais jovens, nele progride lentamente. As afirmações dos informantes nas entrevistas sociolinguísticas e os fatos observados na participação em atividades em Flores da Cunha possibilitaram verificar, em termos de práticas sociais, reprodução dos padrões tradicionais, ligados à história da imigração italiana, na gastronomia, na religião, nas formas de trabalho e de lazer, mas com algumas inovações. Em específico, os jovens, que tendem a palatalizar e fazem a regra progredir na comunidade, deslocam-se diariamente a outras localidades para frequentar faculdade e se divertir, mas retornam a Flores da Cunha, seguem morando nela. Observações como essas revelam um localismo peculiar, permitem-nos compreender o padrão de palatalização da comunidade e apontam a tendência de mudança fônica de progressão moderada no português falado em Flores da Cunha, a ser concretizada pelas gerações futuras.

BATTISTI, E.; DORNELLES FILHO, A. A. The palatalization of dental stops in Flores da Cunha: language variation and social practices. Alfa, São Paulo, v.56, n.3, p.1107-1139, 2012.

- ABSTRACT: The variable palatalization of dental stops in Brazilian Portuguese in the speech community of Flores da Cunha is moderate and contributes to the characterization of the local speech. The variable rule analysis (LABOV, 1972, 1994, 2001, 2010) of data collected from 48 sociolinguistic interviews of the corpus BDSer reveals that the total rate of rule application is $29 \%$. The palatalization is conditioned by both linguistic and social variables and the process progresses in the community: underived high front vowel, voiceless target consonant, young people, inhabitants of the urban area condition palatalization. In the analysis of variation as social practice (ECKERT, 2000), the informants network analysis shows that its high density and the centrality of old subjects refrain palatalization. The ethnographic study reveals that people in Flores da Cunha, especially the young ones, engage in both innovative and traditional social practices and introduce palatalization in the speech community. The palatalization is valued as a non-local practice and a relatively prestigious one.

- KEYWORDS: Language variation. Palatalization. Dental stops. Social practices. 


\section{REFERÊNCIAS}

ALMEIDA, M. A. B. de. A variação das oclusivas dentais na comunidade bilíngue de Flores da Cunha: uma análise quantitativa. 2000. 106 f. Dissertação (Mestrado em Linguística Aplicada) - Pontifícia Universidade Católica do Rio Grande do Sul, Porto Alegre, 2000.

BATTISTI, E. et al. Palatalização das oclusivas alveolares e a rede social dos informantes. Revista Virtual de Estudos da Linguagem: ReVEL, Porto Alegre, v.5, n.9, p.01-29, ago. 2007. Disponível em: <http://www.revel.inf.br/files/artigos/ revel_9_palatalizacao_das_oclusivas_alveolares.pdf>. Acesso em: 27 fev. 2008.

BATTISTI, E.; GUZZO, N. B. Palatalização das oclusivas alveolares: O caso de Chapecó. In: BISOL, L.; COLLISCHONN, G. (Org.). Português no sul do Brasil: variação fonológica. Porto Alegre: EDIPUCRS, 2010. p.114-140.

BISOL, L. A palatalização e sua restrição variável. Estudos: Lingüísticos e Literários, Salvador, v.5, p.151-162, 1986.

. Harmonização vocálica: uma regra variável. 1981. 335f. Tese (Doutorado em Linguística) - Faculdade de Letras, Universidade Federal do Rio de Janeiro, Rio de Janeiro, 1981.

BLAKE, R.; JOSEY, M. The /ay/ diphthong in Martha's Vineyard community: what can we say 40 years after Labov? Language in Society, Cambridge, v.4, n.32, p.451-485, 2003.

BOAVENTURA NETTO, P. O. Grafos: teoria, modelos, algoritmos. São Paulo: Ed. Edgard Blücher, 1996.

BOTTOMORE, T. B. As elites e a sociedade. Rio de Janeiro: Zahar, 1974.

BOURDIEU, P. A economia das trocas linguísticas: o que falar quer dizer. 2.ed. São Paulo: EDUSP, 2008.

CEROUEIRA FILHO, G. A questão social no Brasil: crítica do discurso político. Rio de Janeiro: Civilização Brasileira, 1982.

DUTRA, E. de O. A palatalização das oclusivas dentais /t/ e /d/ no município de Chuí, Rio Grande do Sul. 2007. 129f. Dissertação (Mestrado em Letras) - Faculdade de Letras, Pontifícia Universidade Católica do Rio Grande do Sul, Porto Alegre, 2007. ECKERT, P. Linguistic variation as social practice. Oxford: Blackwell, 2000.

EVANS, B. The role of social network in the acquisition of local dialect norms by Appalachian migrants in Ypsilanti, Michigan. Language Variation and Change, Cambridge, n.16, p.153-167, 2004. 
FROSI, V. M. Provérbios dialetais italianos: uma linguagem em extinção. 1989. $244 f$. Dissertação (Mestrado em Letras) - Faculdade de Letras. Pontifícia Universidade Católica do Rio Grande do Sul, Porto Alegre, 1989.

FROSI, V. M.; MIORANZA, C. Dialetos italianos: um perfil linguístico dos ítalobrasileiros do nordeste do Rio Grande do Sul. Caxias do Sul: EDUCS, 1983.

FRUCHTERMAN, T. M. J.; REINGOLD, E. Graph drawing by force-directed placement. Software: Practice and Experience, London, v.21, n.11, p.1129-1164. 1991.

GERHARDT, G. J. L.; CORSO, G.; LEMKE, N. Network clustering coefficient approach for DNA sequences. Chaos Solitons \& Fractals, Oxford, v.28, n.4, p.1037-1045, 2006.

GUY, G. R. A identidade linguística da comunidade de fala: Paralelismo interdialetal nos padrões de variação linguística. Organon, Porto Alegre, v.14, n.28/29, p.17-32, 2000.

GUZZO, N. B. A elevação da vogal média anterior átona em Flores da Cunha. 2010. 158f. Dissertação (Mestrado em Letras) - Universidade de Caxias do Sul, Caxias do Sul, 2010.

LABOV,W. Principles of linguistic change: social factors. Oxford: Blackwell, 2001. . Principles of linguistic change: internal factors. Oxford: Blackwell, 1994. Sociolinguistic patterns. Philadelphia: University of Philadelphia Press, 1972.

MATHEWS, J. H. Numerical methods for mathematics, science and engineering. Eglewood Cliffs: Prentice Hall, 1992.

MATTÉ, G. D. A palatalização variável de /t d/ em Caxias do Sul. Cadernos do IL, Porto Alegre, n.38, p.43-55, jun. 2009.

MILLS, C. W. A elite no poder. Rio de Janeiro: Zahar, 1962.

MILROY, L. Language and social networks. Oxford: Blackwell, 1980.

NOLL, V. O português brasileiro: formação e contrastes. São Paulo: Globo, 2008.

PAGOTTO, E. G. Variação é identidade. 2001. 454 f. Tese (Doutorado em LetrasLinguística) - Universidade Estadual de Campinas, Campinas, 2001.

ROVEDA, S. D. Elevação da vogal média átona final em comunidades bilíngues: português e italiano. 1998. 81f. Dissertação (Mestrado em Letras) - Faculdade 
de Letras. Pontifícia Universidade Católica do Rio Grande do Sul, Rio Grande do Sul, 1998.

SABBATINI, M.; FRANZINA, E. I veneti in Brasile nel centenario dell'emigrazione (1876-1976). Vicenza: Accademia Olimpica, 1977.

SPRADLEY, J. P. The ethnographic interview. New York: Holt, Rinehart and Winston, 1979.

Recebido em março de 2012

Aprovado em junho de 2012 